\title{
Ractopamine as a Metabolic Modifier Feed Additive for Finishing Pigs: A Review
}

\author{
Vivian Vezzoni de Almeida ${ }^{1 *}$, Amoracyr José Costa Nuñez ${ }^{2}$, Valdomiro Shigueru Miyada ${ }^{1}$ \\ ${ }^{1}$ Escola Superior de Agricultura "Luiz de Queiroz"; Universidade de São Paulo; Av. Pádua Dias, 11; C. P.: 9; \\ 13418-900; Piracicaba - SP - Brasil. ${ }^{2}$ Faculdade de Zootecnia e Engenharia de Alimentos; Universidade de São \\ Paulo; Av. Duque de Caxias Norte, 225; 13635-900; Pirassununga - SP - Brasil
}

\begin{abstract}
The $\beta$-adrenergic agonist ractopamine is increasingly used in the swine industry due to higher consumer demand for leaner pork products. Redirecting nutrients to favor leanness rather than fat deposition, ractopamine improves growth and carcass traits of finishing pigs. However, the impact of this agonist on pork quality is not clearly defined. Understanding the biological effects of dietary ractopamine dose, treatment period, lysine levels, and the lysine to metabolizable energy ratio will help pork producers achieve improvements in animal performance, carcass leanness, and economic efficiency in swine production systems.
\end{abstract}

Key words: $\beta$-adrenergic agonist, carcass leanness, growth, nutrition, swine

\section{INTRODUCTION}

Pork is the most widely consumed form of animal protein in the world, but the consumption of pork products remains low in Brazil. Brazilian per capita pork consumption was only $14.24 \mathrm{~kg}$ in 2009 (ABIPECS 2011), which is much lower than in the European Union, where it was $42.80 \mathrm{~kg}$ in the same year (USDA 2011). The main reason for low Brazilian pork consumption may be related to lingering myths and beliefs concerning the possible negative effects of pork consumption on human health.

Consumer demand for leaner and healthier pork products has risen steadily each year; thus, improvements in animal health, genetics, and especially nutritional technologies, such as the utilization of $\beta$-adrenergic agonists in diets, have become important in helping pork producers to meet this demand. In addition to their use in human and veterinary medicine as bronchodilatory and tocolytic agents (Kuiper et al. 1998), $\beta$ adrenergic agonists increase both lean growth rate and carcass lean percentage (Boler et al. 2010), and improve feed efficiency of finishing pigs (Rikard-Bell et al. 2009; Hinson et al. 2011).

Ractopamine is classified as a $\beta$-adrenergic agonist that acts as a repartitioning agent, redirecting nutrients away from adipose tissue and towards greater muscle deposition. Its use has obtained regulatory approval as a growth-promoting feed additive for swine in the United States, Canada, and Brazil. However, ractopamine is not authorized for use in the European Union or China for growth promotion in farm animals.

The objectives in this review are to highlight the current state of knowledge regarding the modulation of animal growth by ractopamine and to define strategies for optimizing finishing pig responses.

*Author for correspondence: vv.almeida@hotmail.com 


\section{Chemical structure of ractopamine}

Ractopamine is a phenylethanolamine with $\beta$ adrenergic agonist properties similar to the natural catecholamines epinephrine and norepinephrine. The presence of an aromatic ring with a hydroxyl group bound to the $\beta$-carbon, positively charged nitrogen in the ethylamine side chain, and bulky substituent (butyl-phenol group, Fig. 1) on the aliphatic nitrogen makes the molecule more specific to the $\beta$-adrenergic receptor ( $\beta A R$ ) (Smith 1998). Two conformations can arise at each chiral carbon ( $\mathrm{R}$ or $\mathrm{S}$ ); therefore, the commercial preparation of ractopamine is an equimolar mixture of four stereoisomers (RR, RS, SR, and SS) (Ricke et al. 1999).

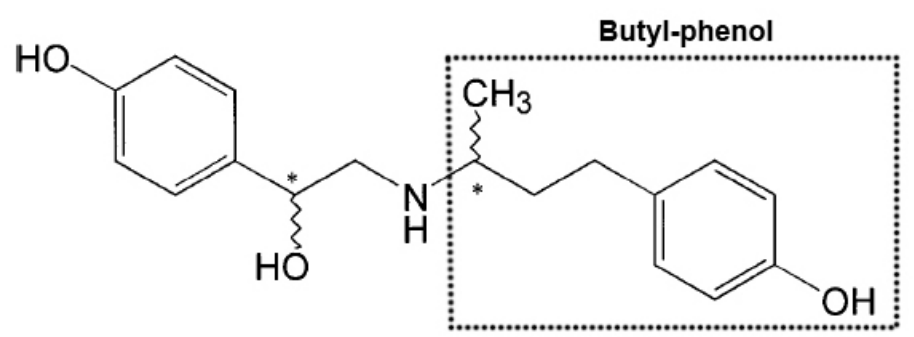

Figure 1 - Chemical structure of ractopamine. Asterisks indicate the locations of the chiral carbons (Modified from Ricke et al. 1999).

\section{$\beta$-adrenergic receptor tissue distribution and ractopamine isomers}

Most mammalian cell types have $\beta A R$ embedded in the plasma membrane. These receptors can be classified into three subtypes: $\beta_{1} \mathrm{AR}, \beta_{2} \mathrm{AR}$, and $\beta_{3} \mathrm{AR}$ (Lands et al. 1967). The predominant subtype expressed in pig tissues is $\beta_{1} A R$, representing $73 \%$ of the total $\beta A R$ in adipose tissue (McNeel and Mersmann 1999) and 59\% in skeletal muscle (Liang and Mills 2002). Porcine skeletal muscle contains $41 \% \quad \beta_{2} \mathrm{AR}$ (Liang and Mills 2002), while 20\% appears in porcine adipocytes (McNeel and Mersmann 1999). However, there is a limited pattern of $\beta_{3} \mathrm{AR}$ expression in most tissues except adipose, where it constitutes $7 \%$ of $\beta A R$ mRNA abundance (McNeel and Mersmann 1999).

Ractopamine is a mixture of four stereoisomers, but not all isomers may be biologically active, and the correct kinetics of the active isomer may be confounded by the presence of competing isomers (Ricke et al. 1999). The RR isomer is likely the functional ligand of ractopamine, but its effectiveness may be compromised by the presence of the RS stereoisomer (Mills et al. 2003a). Moreover, in the cloned receptor model, RR stereoisomers may couple more efficiently to adenyl cyclase through $\beta_{2} \mathrm{AR}$ rather than $\beta_{1} \mathrm{AR}$, even though it exhibits equal affinity to both subtypes (Mills et al. 2003a).

\section{$\beta$-adrenergic receptor signaling pathway}

The transmembrane signaling pathway is initiated by ractopamine binding to $\beta A R$, which activates the guanine nucleotide-binding protein $(G$ protein). $G$ proteins are heterotrimers that consist of the $G_{\alpha}$ and the tightly associated $G_{\beta \gamma}$ subunits; in its inactive form, the $G_{a}$ subunit is coupled with guanosine diphosphate (GDP) (Benovic 1988). Binding of $\beta$-agonists to $\beta A R$ leads to the activation of the $G$ protein-coupled receptor; the $\mathrm{G}_{\alpha}$ subunit releases GDP and binds to guanosine triphosphate (GTP) to activate the subunit. The $\mathrm{G}_{\alpha}$ subunit then dissociates from the $\mathrm{G}_{\beta \gamma}$ dimer and activates adenyl cyclase (AC), which catalyzes the conversion of adenosine triphosphate (ATP) into cyclic adenosine monophosphate (cAMP) (Alberts et al. 2004). The cAMP then binds to the regulatory subunits of cAMP-dependent protein kinase A (PKA), causing a conformational change that releases and activates the catalytic subunits (Benovic 1988). These activated subunits can then phosphorylate various enzymes to mediate cellular responses (Fig. 2).

With prolonged exposure of the cells to ractopamine, the intensity of the receptor-mediated response can be reduced despite the continued presence of the agonist. This diminished responsiveness, termed desensitization, can occur by three main processes: (1) uncoupling of the 
receptors from its $\mathrm{G}$ protein, (2) temporary sequestration and internalization of uncoupled receptors, and (3) degradation of internalized receptors (Alberts et al. 2004). Desensitization can be divided into uncoupling and down-regulation responses (Mills 2002b).

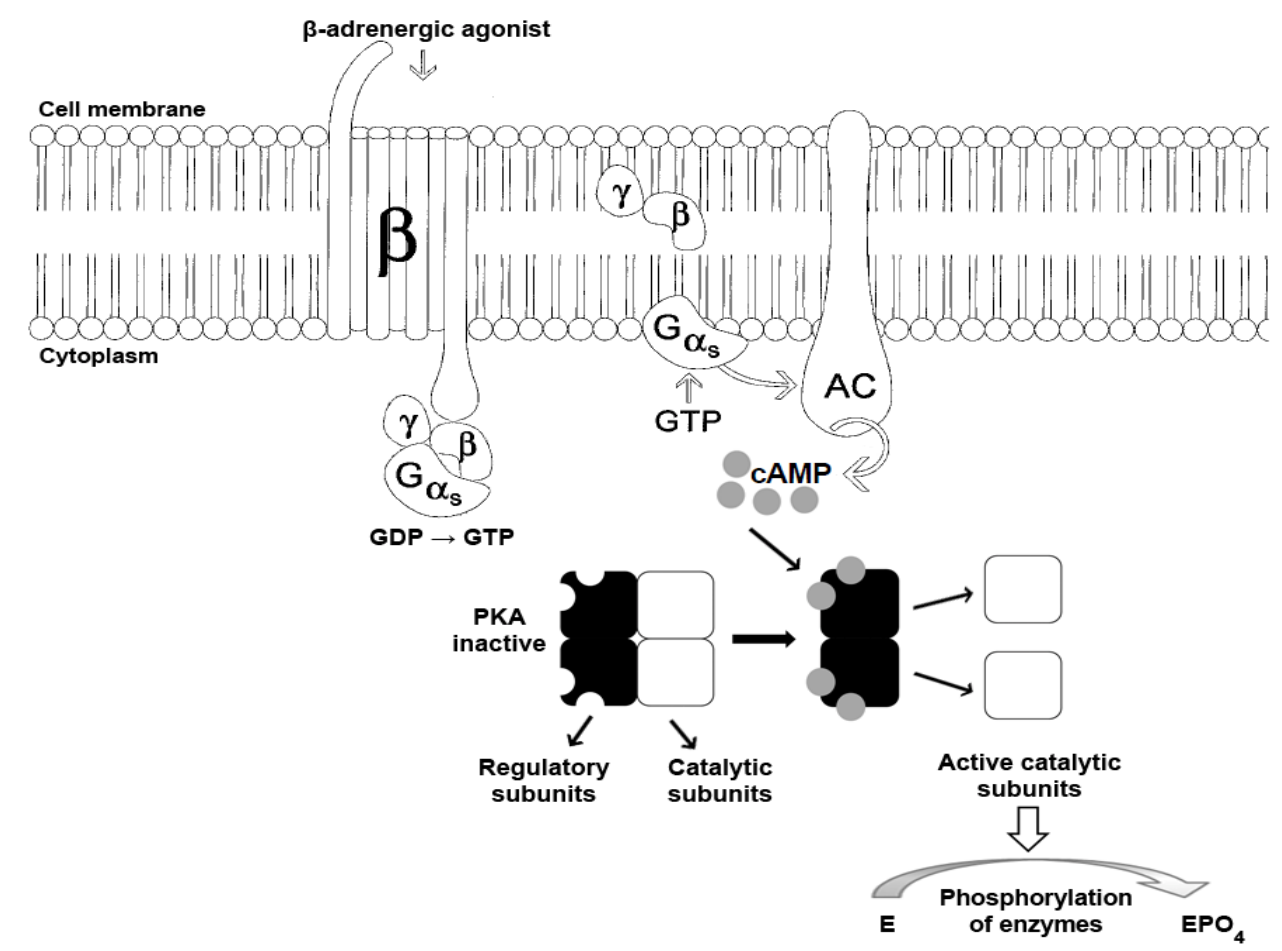

Figure 2 - Intracellular signaling pathways for the $\beta$-adrenergic receptor. $\beta, \beta$-adrenergic receptor; $\gamma / \beta, \gamma$ and $\beta$ subunits of the $G$ protein; $G_{\alpha}, \alpha$ subunit of the $G$ protein; GTP, guanosine triphosphate; AC, adenyl cyclase; ATP, adenosine triphosphate; cAMP, cyclic adenosine monophosphate; PKA, cAMP-dependent protein kinase A; E, enzyme; and $\mathrm{EPO}_{4}$, phosphorylated enzyme (Modified from Barros et al. 1999).

Uncoupling is initiated within seconds to minutes following agonist exposure and involves phosphorylation of $\beta$ AR by PKA, $\beta$-adrenergic receptor kinase 1 ( $\beta$ ARK1), or both (Johnson 2006). Upon agonist stimulation, the $\beta A R K 1$ association with the plasma membrane is facilitated by binding to $G_{\beta \gamma}$ subunits (Mills 2002b). The receptor-agonist complex has a high affinity for $\beta$ ARK1, resulting in the phosphorylation of activated $\beta A R$, which facilitates the inhibitor protein $\beta$-arrestin binding and uncoupling from $G$ protein (Ungerer et al. 1996). Subsequently, $\beta$ AR bound to $\beta$-arrestin is sequestered away from the plasma membrane surface and internalized into cytoplasmic vesicles (Lhose et al. 1990). The receptor is then dephosphorylated, $\beta$-arrestin dissociates, and $\beta A R$ is recycled back to the membrane (Fig. 3). Depending upon the duration of agonist exposure, which can last for hours to days, internalized $\beta A R$ are destroyed, resulting in a net loss of available membrane receptors. During this process, which is called down-regulation, $\beta A R$ is ubiquitinated by E3 ubiquitin-protein ligase which activates the process of receptor degradation in the lysosomes (Johnson 2006). Both processes, uncoupling and down-regulation, contribute to a reduction in total $\beta A R$ in the plasma membrane (Mills 2002b). 


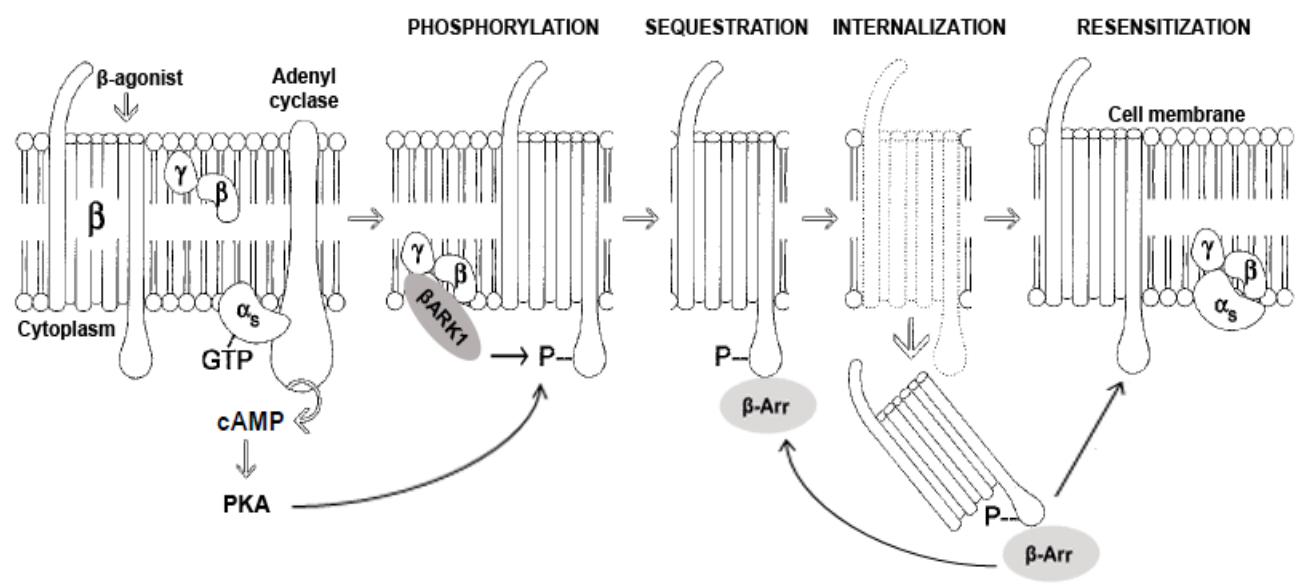

Figure 3 - $\beta$-adrenergic receptor desensitization and resensitization. $\beta, \beta$-adrenergic receptor; $\alpha, \alpha$ subunit of the $\mathrm{G}$ protein; $\gamma / \beta, \gamma$ and $\beta$ subunits of the $\mathrm{G}$ protein; GTP, guanosine triphosphate; cAMP, cyclic adenosine monophosphate; PKA, cAMP-dependent protein kinase A; $\beta$ ARK1, $\beta$-adrenergic receptor kinase 1 ; $\mathrm{P}$, phosphorylation; and $\beta$-Arr, $\beta$ arrestin (Modified from Barros et al. 1999).

\section{Metabolic responses induced by ractopamine}

The main effect of feeding ractopamine to pigs is muscle cell hypertrophy that enhances lean mass, which may result from increased muscle protein synthesis, decreased protein degradation, or both (Mersmann 1998). Bergen et al. (1989) observed daily increases in fractional protein synthesis rates from 4.4 to $6.1 \%$ in muscle of pigs fed $20 \mathrm{ppm}$ ractopamine. Similar results were reported by Grant et al. (1993), in which $\alpha$-actin mRNA abundance was increased by feeding ractopamine to pigs. Ractopamine also increased the proliferation of chick satellite cells in culture (Grant et al. 1990), but the recruitment of additional satellite cell nuclei does not appear to be a prerequisite for the accelerated accretion of skeletal muscle because DNA concentrations were not enhanced with ractopamine supplementation (Grant et al. 1993). On the other hand, the hypertrophic effect of ractopamine may be the result of a decreased rate of muscle protein degradation, as calpain I activity was reduced in the muscles of pigs fed $20 \mathrm{ppm}$ ractopamine for three weeks prior to slaughter (Sainz et al. 1993). Moreover, the repartitioning of energy by ractopamine can increase blood flow to skeletal muscle, supporting the idea that $\beta$-adrenergic agonists could readily enhance the process of hypertrophy by increasing the provision of substrates and energy sources for protein synthesis (Mersmann 1998).
Reductions in plasma urea concentrations have also been reported in pigs fed ractopamine. According to See et al. (2004), a decline in the circulating plasma urea concentration results from an increase in muscle protein synthesis promoted by ractopamine, which consequently elevates nitrogen utilization. The reduction in plasma urea occured within 30 hours of ractopamine feeding, and its withdrawal caused a marked increase $(21 \%)$ circulating plasma urea nitrogen (Dunshea and King 1994). Pigs receiving 5 ppm ractopamine showed a decrease of $12 \%$ in plasma urea concentrations within 14 days of feeding, but not within 28 days; thus, the agonist may act more efficiently on protein metabolism during the first 14 days of supplementation (Cantarelli et al. 2009a).

In adipocytes, stimulation of $\beta$ AR by ractopamine promotes an increase in lipolysis and an inhibition of fatty acids and triacylglycerol synthesis (Mersmann 1998), the opposite of insulin action, which stimulates lipogenesis in swine adipose tissue. Under appropriate in vitro conditions, Liu and Mills (1990) found that ractopamine can inhibit insulin binding in approximately $10 \%$; ractopamine therefore antagonizes insulin action in pig adipocytes. Additionally, ractopamine supplementation at $20 \mathrm{ppm}$ interacts in vivo with the $\beta A R$ of swine adipocytes, suppressing the activity of lipogenic enzymes and the capacity for de novo fatty acid synthesis (Mills et al. 1990). Direct activation of $\beta A R$ in pig adipose tissue by 
ractopamine stimulated the in vitro release of glycerol and free fatty acids through increased lipolysis (Peterla and Scanes 1990).

The oral administration of ractopamine to pigs promoted lower fat accretion due to an attenuation of lipogenesis (Bergen 2001). Likewise, recent studies focusing on lipogenic gene expression have indicated that ractopamine reduces the expression of lipid synthesis genes, such as sterol regulatory element binding protein-1 (SREBP-1) and fatty acid synthase (FAS), in the adipose tissue of finishing pigs (Reiter et al. 2007; Halsey et al. 2011). Furthermore, the expression of peroxisome proliferator-activated receptor $\gamma 2$ (PPAR $\gamma 2)$, a transcription factor involved in adipogenesis, was decreased when pigs were fed ractopamine for 28 and 42 days (Halsey et al. 2011). Thus, lipolysis may not be the primary contributor to decrease fat deposition in ractopamine-fed pigs. Ractopamine can also trigger the apoptotic process in mouse adipose tissue (Page et al. 2004), which may partially explain the reduction in carcass fat of pigs (Weber et al. 2006).

Ractopamine has been evaluated for possible effects on animal welfare. As suggested by Schaefer et al. (1992), the utilization of ractopamine in swine finishing diets did not cause marked changes in animal behavior even though pigs spent more time lying and less time walking during a 4-hour period. In contrast, MarchantForde et al. (2003) observed that pigs fed 10 ppm ractopamine for four weeks were more active and had elevated heart rates and circulating catecholamine levels, making them more difficult to handle and potentially more susceptible to stress during handling and transport. Gilts demonstrated increased aggressiveness, and ractopamine appears to intensify this behavior (Poletto et al. 2010).

\section{Modulation of lipid metabolism by ractopamine} Ractopamine may have a direct effect on porcine lipid metabolism due to both increased lipolysis (Fain and García-Sáinz 1983; Peterla and Scanes 1990) and reduced lipogenesis (Bergen 2001; Reiter et al. 2007; Halsey et al. 2011). However, reductions in fat deposition induced by ractopamine have not been clearly observed (Dunshea et al. 1993, 1998; Carr et al. 2005b; Fernández-Dueñas et al. 2008; Moore et al. 2009; Boler et al. 2010; Kutzler et al. 2010). Because literature reports regarding the effects of ractopamine on fat accretion are inconclusive, in vitro assays were developed to explain the possible irresponsiveness of ractopamine in adipose tissue metabolism. Mills (2000) suggested that $\beta_{1} A R$ is the major regulator of lipolysis in pigs and that $\beta_{2}$ AR may not be linked to the lipolytic cascade, possibly due to intracellular compartmentalization. Despite $\beta_{1}$ AR being the predominant subtype in swine adipocytes, the RR isomer might preferentially target $\beta_{2} \mathrm{AR}$, and ractopamine may therefore have limited effectiveness in reducing fat accretion in pigs (Mills et al. 2003a). Mills et al. (2003b) demonstrated that stimulation of lipolysis by the RR isomer was mediated predominantly through $\beta_{2} \mathrm{AR}$, thus making it a full agonist through this receptor. However, both $\beta_{1} \mathrm{AR}$ and $\beta_{2} \mathrm{AR}$ contributed to the stimulation of lipolysis by $\mathrm{RR}$ in swine adipocytes, because $\beta_{2} \mathrm{AR}$ intracellular compartmentalization was not confirmed. As a result, a molecule with full agonist activity through $\beta_{1} \mathrm{AR}$ could likely promote greater reductions in fat accretion (Mills et al. 2003b).

Besides the distribution patterns of $\beta$ AR subtypes in porcine adipose tissue as previously mentioned, chronic ractopamine feeding can compromise the reduction in adipose deposition. Prolonged exposure to ractopamine progressively decreased $\beta A R$ in the subcutaneous adipose tissue of pigs by $28 \%$ within one day and $53 \%$ within eight days because of the down-regulation of $\beta A R$ that limits ractopamine response in this tissue (Spurlock et al. 1994). On the other hand, Smith (1989) failed to detect down-regulation of $\beta A R$ in the skeletal muscle of ractopamine-fed pigs. This difference may indicate that muscle tissue can be a more responsive target for ractopamine than adipose tissue (Liu et al. 1994), or, perhaps, that ractopamine stimulates the synthesis of new $\beta A R$ protein in skeletal muscle, which effectively masks down-regulation (Mills 2002b). Choosing a more potent agonist, increasing ractopamine dose, or using treatment regimens that circumvent agonistinduced receptor down-regulation could have an enhanced capacity to reduce lipid accretion (Liu et al. 1994).

\section{Ractopamine: growth performance and carcass traits of finishing pigs}

Ractopamine is able to produce maximum lean gain at a low energy intake by repartitioning energy for maximal protein deposition (Williams et al. 1994). These authors further observed that an energy intake above $8.3 \mathrm{Mcal}$ of metabolizable energy per day (ME/d) for barrows and 7.7 Mcal 
of $\mathrm{ME} / \mathrm{d}$ for gilts was deposited as fat. However, a recent study demonstrated that ractopamine supplementation resulted in enhanced lean deposition regardless of dietary energy levels (Hinson et al. 2011). Furthermore, the lysine to metabolizable energy ratio (Lys:ME) may impact performance and carcass characteristics in ractopamine-fed pigs more than absolute energy intake values (Apple et al. 2004). These authors concluded that $3.30 \mathrm{Mcal}$ of ME/kg are enough to optimize lean tissue deposition in pigs fed $10 \mathrm{ppm}$ ractopamine and that both performance and carcass traits improved as the Lys:ME ratio increased from 1.7 to $3.1 \mathrm{~g} / \mathrm{Mcal}$. Likewise, the addition of $10 \mathrm{ppm}$ ractopamine to pig diets containing $3.1 \mathrm{~g} / \mathrm{Mcal}$ Lys:ME and $3.48 \mathrm{Mcal}$ of $\mathrm{ME} / \mathrm{kg}$ improved rate and efficiency of gain, carcass leanness, and meat quality (Apple et al. 2008).

It has been repeatedly shown that including ractopamine in swine finishing diets improves feed efficiency (Webster et al. 2007; Apple et al. 2008; Main et al. 2009; Poletto et al. 2009; Rikard-Bell et al. 2009; Edmonds and Baker 2010; Hinson et al. 2011). Because less dietary energy is required to deposit muscle tissue in comparison with adipose tissue, ractopamine-treated pigs present enhanced growth rates and efficiencies of gain (Schinckel et al. 2003).

In a meta-analysis involving dietary levels of ractopamine $(0,5,10$, and $20 \mathrm{ppm})$, Kiefer and Sanches (2009) observed quadratic improvements in average daily gain and feed to gain ratio as the inclusion of ractopamine increased in the diets of finishing pigs, concluding that 15 ppm ractopamine optimized animal performance. However, performance enhancements in modern high-lean-gain pigs are achieved efficiently with just 5 ppm ractopamine (Schinckel et al. 2002). One of the most important things to consider regarding the utilization of ractopamine is that the response is not constant over time. Williams et al. (1994) showed that maximum growth response occurred during the first three weeks of ractopamine feeding, while Mills (2002a) observed that the agonist response was greater during the first week of utilization and decreased as the program extended from four to six weeks. This effect occurs when ractopamine is fed at a constant level over long periods, as a result of down-regulation, desensitization of $\beta A R$, or both. Therefore, implementing feeding strategies may enhance the ability of response to ractopamine supplementation (Table 1).

Implementation of a ractopamine step-up feeding regimen (i.e., ractopamine concentrations increasing over time) enhances average daily gain and feed efficiency of pigs (Poletto et al., 2009). Similarly, previous reports from See et al. (2004) indicated that ractopamine step-up or constant feeding programs resulted in greater benefits in live-animal performance, and yielded more lean pork in comparison with a step-down feeding regimen (i.e., decreasing dietary concentrations of ractopamine throughout the feeding period). Moreover, Jacela et al. (2009) proposed that feeding ractopamine to pigs at a constant level of $4.5 \mathrm{ppm}$ during the last 21 days prior to market is ideal for growth performance, but if pigs could not be marketed in a timely manner, then it is recommended to increase dietary levels of ractopamine.

Because ractopamine increases protein deposition, the percentage of protein accretion deposited in muscle tissues increases from 54.0 to 59.4, 60.3, and $61.65 \%$, and the lysine content of the protein accretion increases from 6.80 to $7.05,7.09$, and $7.15 \%$ as ractopamine concentration increases from 0 to 5,10 , and $20 \mathrm{ppm}$, respectively (Schinckel et al. 2003). Consequently, pigs receiving ractopamine require increased amounts of limiting amino acids, especially lysine. Protein tissue deposition is the only major function of lysine in the animal body, thus its requirement is not influenced by other metabolic roles.

Finishing pigs fed ractopamine require at least $0.88 \%$ dietary digestible lysine to optimize growth performance, carcass traits, and tissue accretion (Webster et al. 2007). Marinho et al. (2007) reported improved performance of finishing pigs fed ractopamine with diets containing $0.67 \%$ digestible lysine; however, with $0.87 \%$ digestible lysine, pigs showed decreased backfat thickness and increased carcass lean percentage, loin depth, and lean meat deposition. Pigs receiving diets containing low crude protein $(12.5 \%)$ and lysine $(0.49 \%)$ levels for 14 days, followed by a subsequent 21-day period receiving higher crude protein $(20.33 \%)$ and lysine $(0.99 \%)$ levels, can recover and present similar growth performance and carcass merit in comparison with those in a conventional protein feeding regimen (Edmonds and Baker 2010). When developing a model of dietary lysine requirements for ractopamine-fed 
pigs, Schinckel et al. (2001) concluded that the predicted lysine requirement for pigs quickly increases during the first week of ractopamine feeding and then declines; thus, pork producers should consider phase feeding with two or three diets containing different lysine levels. According to Schinckel et al. (2006), step-up programs can enhance the duration of ractopamine response, but only if dietary lysine levels are increased. In addition, the greatest economic benefit from ractopamine step-up programs is achieved when producers receive carcass premiums (Canchi et al. 2009).

Table 1 - Effects of ractopamine feeding strategies on growth performance and carcass traits of finishing pigs

\begin{tabular}{|c|c|c|c|c|c|c|c|c|c|}
\hline \multirow{2}{*}{ Reference } & \multirow[b]{2}{*}{ Ractopamine Feeding Strategies } & \multirow[b]{2}{*}{ Sex } & \multicolumn{5}{|c|}{ Performance $^{1}$} & \multicolumn{2}{|c|}{ Carcass Trait $^{2}$} \\
\hline & & & $\begin{array}{c}\text { FBW } \\
(\mathbf{k g})\end{array}$ & $\begin{array}{c}\text { ADFI } \\
(\mathrm{kg})\end{array}$ & $\begin{array}{c}\text { ADG } \\
(\mathrm{kg})\end{array}$ & G:F & F:G & $\begin{array}{l}\text { LMA } \\
\left(\mathrm{cm}^{2}\right)\end{array}$ & $\begin{array}{l}\text { 10th-rib } \\
\text { fat depth } \\
(\mathrm{cm})\end{array}$ \\
\hline \multirow{4}{*}{$\begin{array}{l}\text { See et al. } \\
(2004)\end{array}$} & $0 \mathrm{ppm}$ for $41 \mathrm{~d}$ & \multirow{4}{*}{$\begin{array}{l}\text { barrows } \\
\text { and gilts }\end{array}$} & 109.60 & 2.98 & $0.930^{\mathrm{b}}$ & $0.310^{\mathrm{b}}$ & - & $43.40^{\mathrm{c}}$ & $1.47^{\mathrm{a}}$ \\
\hline & $\begin{array}{l}5 \mathrm{ppm} \text { for } 14 \mathrm{~d}, 10 \mathrm{ppm} \text { for } 14 \mathrm{~d} \text { and } 20 \\
\text { ppm for } 13 \mathrm{~d}\end{array}$ & & 111.80 & 2.75 & $1.000^{\mathrm{a}}$ & $0.360^{\mathrm{a}}$ & - & $50.50^{\mathrm{a}}$ & $1.07^{\mathrm{b}}$ \\
\hline & $\begin{array}{l}20 \mathrm{ppm} \text { for } 14 \mathrm{~d}, 10 \mathrm{ppm} \text { for } 14 \mathrm{~d} \text { and } 5 \\
\text { ppm for } 13 \mathrm{~d}\end{array}$ & & 111.20 & 2.78 & $1.000^{\mathrm{a}}$ & $0.360^{\mathrm{a}}$ & - & $47.30^{\mathrm{b}}$ & $1.09^{\mathrm{b}}$ \\
\hline & $11.7 \mathrm{ppm}$ for $41 \mathrm{~d}$ & & 113.00 & 2.75 & $1.000^{\mathrm{a}}$ & $0.360^{\mathrm{a}}$ & - & $49.40^{\mathrm{ab}}$ & $1.17^{\mathrm{b}}$ \\
\hline \multirow{4}{*}{$\begin{array}{l}\text { Armstrong } \\
\text { et al. } \\
\text { (2005) }\end{array}$} & $0 \mathrm{ppm}$ for $35 \mathrm{~d}$ & \multirow{4}{*}{$\begin{array}{l}\text { barrows } \\
\text { and gilts }\end{array}$} & $102.70^{\mathrm{b}}$ & 2.25 & $0.700^{\mathrm{a}}$ & - & $3.24^{\mathrm{a}}$ & - & 1.65 \\
\hline & $5 \mathrm{ppm}$ for $35 \mathrm{~d}$ & & $105.30^{\mathrm{a}}$ & 2.27 & $0.760^{\mathrm{b}}$ & - & $3.00^{\mathrm{b}}$ & - & 1.60 \\
\hline & $5 \mathrm{ppm}$ for $14 \mathrm{~d}$ and $10 \mathrm{ppm}$ for $21 \mathrm{~d}$ & & $106.50^{\mathrm{a}}$ & 2.25 & $0.800^{\mathrm{c}}$ & - & $2.82^{\mathrm{c}}$ & - & 1.63 \\
\hline & $5 \mathrm{ppm}$ for $21 \mathrm{~d}$ and $10 \mathrm{ppm}$ for $14 \mathrm{~d}$ & & $106.90^{\mathrm{a}}$ & 2.29 & $0.810^{\mathrm{c}}$ & - & $2.82^{\mathrm{C}}$ & - & 1.57 \\
\hline \multirow{3}{*}{$\begin{array}{l}\text { Jacela et } \\
\text { al. (2009) }\end{array}$} & $0 \mathrm{ppm}$ for $28 \mathrm{~d}$ & \multirow{3}{*}{$\begin{array}{l}\text { barrows } \\
\text { and gilts }\end{array}$} & 114.76 & 2.69 & $0.798^{\mathrm{a}}$ & - & $3.39^{\mathrm{a}}$ & - & $1.73^{\mathrm{a}}$ \\
\hline & $0 \mathrm{ppm}$ for $7 \mathrm{~d}$ and $4.5 \mathrm{ppm}$ for $21 \mathrm{~d}$ & & 118.98 & 2.68 & $0.948^{\mathrm{b}}$ & - & $2.82^{\mathrm{b}}$ & - & $1.68^{\mathrm{a}}$ \\
\hline & $4.5 \mathrm{ppm}$ for $14 \mathrm{~d}$ and $6.75 \mathrm{ppm}$ for $14 \mathrm{~d}$ & & 118.71 & 2.59 & $0.929^{\mathrm{b}}$ & - & $2.79^{\mathrm{b}}$ & - & $1.57^{\mathrm{b}}$ \\
\hline \multirow{3}{*}{$\begin{array}{l}\text { Moore et } \\
\text { al. }(2009)\end{array}$} & $0 \mathrm{ppm}$ for $26 \mathrm{~d}$ & \multirow[t]{3}{*}{$\begin{array}{l}\text { immunocastrated } \\
\text { males }\end{array}$} & $115.00^{\mathrm{b}}$ & 3.89 & $1.200^{\mathrm{b}}$ & - & $3.26^{\mathrm{a}}$ & - & 1.53 \\
\hline & $5 \mathrm{ppm}$ for $26 \mathrm{~d}$ & & $116.30^{\mathrm{a}}$ & 3.62 & $1.270^{\mathrm{a}}$ & - & $2.87^{\mathrm{b}}$ & - & 1.43 \\
\hline & $5 \mathrm{ppm}$ for $14 \mathrm{~d}$ and $10 \mathrm{ppm}$ for $12 \mathrm{~d}$ & & $117.40^{\mathrm{a}}$ & 3.75 & $1.300^{\mathrm{a}}$ & - & $2.91^{\mathrm{b}}$ & - & 1.45 \\
\hline \multirow{2}{*}{$\begin{array}{l}\text { Poletto et } \\
\text { al. (2009) }\end{array}$} & $0 \mathrm{ppm}$ for $28 \mathrm{~d}$ & barrows & $117.84^{\mathrm{b}}$ & 2.97 & $0.898^{\mathrm{b}}$ & $0.307^{\mathrm{b}}$ & - & - & - \\
\hline & $5 \mathrm{ppm}$ for $14 \mathrm{~d}$ and $10 \mathrm{ppm}$ for $14 \mathrm{~d}$ & and gilts & $122.58^{\mathrm{a}}$ & 2.91 & $1.044^{\mathrm{a}}$ & $0.358^{\mathrm{a}}$ & - & - & - \\
\hline \multirow{2}{*}{$\begin{array}{l}\text { Rikard- } \\
\text { Bell et al. } \\
\text { (2009) }\end{array}$} & $0 \mathrm{ppm}$ for $31 \mathrm{~d}$ & \multirow{2}{*}{$\begin{array}{l}\text { immunocastrated } \\
\text { males }\end{array}$} & $108.40^{\mathrm{b}}$ & 3.65 & $1.240^{\mathrm{b}}$ & $0.339^{\mathrm{b}}$ & - & - & - \\
\hline & $5 \mathrm{ppm}$ for $14 \mathrm{~d}$ and $10 \mathrm{ppm}$ for $17 \mathrm{~d}$ & & $109.90^{\mathrm{a}}$ & 3.43 & $1.270^{\mathrm{a}}$ & $0.370^{\mathrm{a}}$ & - & - & - \\
\hline \multirow{4}{*}{$\begin{array}{l}\text { Neill et } \\
\text { al. }(2010)\end{array}$} & $0 \mathrm{ppm}$ for $56 \mathrm{~d}$ & \multirow{4}{*}{$\begin{array}{l}\text { barrows } \\
\text { and gilts }\end{array}$} & $120.40^{\mathrm{b}}$ & 2.87 & $0.940^{\mathrm{b}}$ & $0.330^{\mathrm{b}}$ & - & - & - \\
\hline & $10 \mathrm{ppm}$ for $21 \mathrm{~d}$ and $0 \mathrm{ppm}$ for $35 \mathrm{~d}$ & & $120.70^{\mathrm{b}}$ & 2.85 & $0.950^{\mathrm{b}}$ & $0.330^{\mathrm{b}}$ & - & - & - \\
\hline & $\begin{array}{l}10 \mathrm{ppm} \text { for } 21 \mathrm{~d}, 0 \mathrm{ppm} \text { for } 14 \mathrm{~d} \text { and } 10 \\
\mathrm{ppm} \text { for } 21 \mathrm{~d}\end{array}$ & & $123.40^{\mathrm{a}}$ & 2.83 & $1.000^{\mathrm{a}}$ & $0.360^{\mathrm{a}}$ & - & - & - \\
\hline & $0 \mathrm{ppm}$ for $35 \mathrm{~d}$ and $10 \mathrm{ppm}$ for $21 \mathrm{~d}$ & & $123.80^{\mathrm{a}}$ & 2.83 & $1.000^{\mathrm{a}}$ & $0.350^{\mathrm{a}}$ & - & - & - \\
\hline
\end{tabular}

${ }^{1}$ FBW, final body weight; ADG, average daily gain; ADFI, average daily feed intake; G:F, gain:feed ratio (feed efficiency); F:G, feed:gain ratio (feed conversion).

${ }^{2}$ LMA, Longissimus muscle area.

${ }_{\mathrm{a}, \mathrm{b}, \mathrm{c}}$ Within a column, means with different superscripts $\operatorname{differ}(P<0.05)$.

In the past, pork producers were paid strictly on a live-weight basis; thus, little attention was given to the composition of gain, which often resulted in carcasses with excessive amounts of fat. Today, the relative value of carcass lean to carcass fat becomes an economically important factor because carcass merit pricing and evaluation systems have been adopted in the pork industry.

Cantarelli et al. (2009b) observed a 3.9\% increase in carcass premiums for pigs supplemented with 5 ppm ractopamine in comparison with control animals. These results are in agreement with those obtained by Corassa et al. (2009), who reported that pigs receiving $5 \mathrm{ppm}$ ractopamine produced $4.9 \%$ more meat and had a $2.2 \%$ increase in carcass premiums when compared to those without supplementation. According to Li et al. (2003), the positive impact is defined by the payments that pork producers receive for lean meat in relation to fat tissue and the discount/premium schedules. The maximum profit was obtained with ractopamine levels of 10 and $12 \mathrm{ppm}$ for the systems of revenue/live weight and revenue/carcass premium, respectively, but the system of revenue/carcass premium was more economically viable (Brumatti and Kiefer 2010). The economically optimal 
management of ractopamine concentrations, feeding duration, and lysine levels are therefore determined by the economic return for increased leanness, including costs of feed and feed additives.

\section{Impact of ractopamine on pork quality}

The effects of ractopamine on meat quality in pigs have been reported in the literature, but the results remain inconsistent and inconclusive. Feeding ractopamine to finishing pigs does not have an adverse effect on initial $\mathrm{pH}$ (45 min postmortem), ultimate $\mathrm{pH}$ ( $24 \mathrm{~h}$ postmortem), or drip loss (Carr et al. 2005a). Other studies have reported that drip loss percentage and redness and yellowness of the Longissimus dorsi decreased in response to dietary ractopamine (Webster et al. 2007; Apple et al. 2008; Almeida et al. 2010; Kutzler et al. 2010; Leick et al. 2010), but Carr et al. (2009) did not observe any difference in subjective color score when pigs were fed 0,5 , and $20 \mathrm{ppm}$ ractopamine. The available literature has established that supplementing finishing pig diets with 5,10 , or 20 ppm ractopamine increases Warner-Bratzler shear force values (Carr et al. 2005a, b; Xiong et al. 2006; Fernández-Dueñas et al. 2008). One possible explanation is that ractopamine increases muscle calpastatin activity and reduces calpain activity; in other words, the reduction in postmortem proteolysis of myofibrillar protein provides higher shear force values, or reduced meat tenderness (Xiong et al. 2006). The accretion of fast white fibers, which have larger diameters, may contribute to the reduced meat tenderness observed with dietary ractopamine supplementation (Carr et al. 2005b). Despite the fact that ractopamine feeding increased meat toughness, the effects may be reduced if pig carcasses or carcass cuts are aged for a prolonged period, or submitted to other suitable postmortem handling and storage conditions (Xiong et al. 2006).

\section{Ractopamine residues in animal tissues}

The presence of drug residues in the tissues of treated animals, especially when the compound has been used illegally or in an off-label manner, is a concern for food quality and safety. Ractopamine has obtained regulatory approval as a feed additive in swine production in more than 20 countries, including the United States, Canada, and Brazil. However, this repartitioning drug is forbidden in the European Union and China due to several reported cases of clenbuterol food poisoning (Kuiper et al. 1998; Qiang et al. 2007).

Ractopamine residues found after the discontinuation of exposure have been reported for cattle and sheep (Smith and Shelver 2002). This study showed that ractopamine may be detected for at least seven or five days after the last exposure in the urine of sheep and cattle, respectively.

In a depletion study, Qiang et al. (2007) measured ractopamine residues in the tissues of pigs after administration of $20 \mathrm{ppm}$ dietary ractopamine for 28 days. These authors reported that while residues in muscle and fat were not detectable 24 hours after the last agonist exposure, residues in kidney remained higher than those in liver throughout the withdrawal period. Ractopamine concentrations in liver, kidney, muscle, and fat tissues of pigs during the withdrawal period were lower than the tolerance values established by the Food and Drug Administration (FDA) and the Maximum Residue Levels (MRL) listed by the Joint FAO/WHO Expert Committee on Food Additives (JECFA).

In order to monitor the illegal use of ractopamine, it is necessary to develop proper residue detection methods in swine tissues, feeds, and urine. Recent researches have suggested instrumental methods to detect these residues (Sakai et al. 2007; Shen et al. 2007; Zhang et al. 2009; Zhai et al. 2011), but no mention of ractopamine-withdrawal period for finishing pigs were made. In this way, further studies are required to determine whether consumer safety can be assured without applying a ractopamine-withdrawal period.

\section{CONCLUSION}

The $\beta$-adrenergic agonist ractopamine has been increasingly used in the swine industry due to its ability to improve performance and carcass leanness, resulting in enhanced opportunities for improving the profitability of producers. In comparison with constant and step-down programs, greater animal responses to ractopamine step-up programs have been reported; however, pork producers should consider implementing this feeding strategy when lean carcasses are rewarded. 


\section{ACKNOWLEDGEMENT}

We are grateful to FAPESP for financial support and for a doctoral scholarship.

\section{REFERENCES}

ABIPECS - Associação Brasileira da Indústria Produtora e Exportadora de Carne Suína [Internet]. 2011 Apr 10 [update 2011 Apr 10, cited 2011 Apr 10]. Available from: http://www.abipecs.org.br/uploads/relatorios/mercado -interno/consumo/Oferta_e_demanda.pdf.

Alberts B, Johnson A, Lewis J, Raff M, Roberts K, Walter P. Comunicação cellular. In: Alberts B, Johnson A, Lewis J, Raff M, Roberts K, Walter P, editors. Biologia Molecular da Célula. São Paulo: Artmed; 2004. p. 831-906.

Almeida VV, Berenchtein B, Costa LB, Tse MLP, Braz DB, Miyada VS. Ractopamina, cromo-metionina e suas combinações como aditivos modificadores do metabolismo de suínos em crescimento e terminação. Rev. Bras.Zootec. 2010; 39(9): 1969-1977. Portuguese.

Apple JK, Maxwell CV, Brown DC, Friesen KG, Musser RE, Johnson ZB, et al. Effects of dietary lysine and energy density on performance and carcass characteristics of finishing pigs fed ractopamine. $J$. Anim. Sci. 2004; 82(11): 3277-3287.

Apple JK, Maxwell CV, Kutz BR, Rakes LK, Sawyer JT, Johnson ZB, et al. Interactive effect of ractopamine and dietary fat source on pork quality characteristics of fresh pork chops during simulated retail display. J. Anim. Sci. 2008; 86(10): 2711-2722.

Armstrong TA, Kremer BT, Marsteller TA, Mechler D. Effects of ractopamine step-up use programs on finishing pigs fed under commercial conditions. $J$. Swine Health Prod. 2005; 13(2): 66-71.

Barros RA, Okoshi MP, Cicogna AC. Beta-adrenergic pathway in healthy and hypertrophied hearts. Arq. Bras. Cardiol. 1999; 72(5): 649-656.

Benovic JL, Bouvier M, Caron MG, Lefkowitz RJ. Regulation of adenylyl cyclase-coupled $\beta$-adrenergic receptors. Annu. Rev. Cell. Biol. 1988; 4: 405-428.

Bergen WG, Johnson SE, Skjaerlund DM, Babiker AS, Ames NK, Merkel RA, et al. Muscle protein metabolism in finishing pigs fed ractopamine. $J$. Anim. Sci.1989; 67(9): 2255-2262.

Bergen, WG. The role of cAMP elevating agents and somatotropin on pre- and posttranslational regulation of lipogenesis and lipolysis in Bos taurus and Sus scrofa. Recent Res. Dev. Lipids 2001; 5: 47-59.
Boler DD, Holmer SF, Duncan DA, Carr SN, Ritter MJ, Stites CR, et al. Fresh meat and further processing characteristics of ham muscles from finishing pigs fed ractopamine hydrochloride. J. Anim. Sci. 2010; 89(1): 210-220.

Brumatti RC, Kiefer C. Simulação técnico-econômica da inclusão de ractopamina em dietas de suínos em terminação. Arq. Bras. Med. Vet. Zootec. 2010; 62(1): 163-171. Portuguese.

Canchi D, Li N, Foster K, Preckel PV, Schinckel A, Richert B. Optimal control of desensitizing inputs: the case of paylean. Amer. J. Agr. Econ. 2009; 92(1): 56-69.

Cantarelli VS, Fialho ET, Almeida EC, Zangeronimo MG, Rodrigues PB, Freitas RTF. Ractopamine for finishing barrows fed restricted or ad libitum diets: performance and nitrogen balance. Rev. Bras. Zootec. 2009a; 38(12): 2375-2382.

Cantarelli VS, Fialho ET, Almeida EC, Zangeronimo MG, Amaral NO, Lima JAF. Características da carcaça e viabilidade econômica do uso de cloridrato de ractopamina para suínos em terminação com alimentação à vontade ou restrita. Cienc. Rural 2009b; 39(3): 844-851. Portuguese.

Carr SN, Rincker PJ, Killefer J, Baker DH, Ellis M, McKeith FK. Effects of different cereal grains and ractopamine hydrochloride on performance, carcass characteristics, and fat quality in late-finishing pigs. J. Anim. Sci. 2005a; 83(1): 223-230.

Carr SN, Ivers DJ, Anderson DB, Jones DJ, Mowrey $\mathrm{DH}$, England $\mathrm{MB}$, et al. The effects of ractopamine hydrochloride on lean carcass yields and pork quality characteristics. J. Anim. Sci. 2005b; 83(12): 28862893.

Carr SN, Hamilton DN, Miller KD, Schroeder AL, Fernández-Dueñas D, Killefer J, et al. The effect of ractopamine hydrochloride (Paylean) on lean carcass yields and pork quality characteristics of heavy pigs fed normal and amino acid fortified diets. Meat. Sci. 2009; 81: 533-539.

Corassa A, Lopes DC, Teixeira AO. Ractopamina e fitase em dietas para suínos na fase de terminação. Rev. Bras. Zootec.2009; 38(11): 2174-2181. Portuguese.

Dunshea FR, King RH, Campbell RG. Interrelationships between dietary protein and ractopamine on protein and lipid deposition in finishing gilts. J. Anim. Sci. 1993; 71(11): 2931-2941.

Dunshea FR, King RH. Temporal response of plasma metabolites to ractoparnine treatment in the growing pig. Aust. J. Agr. Res. 1994; 45(8): 1683-1692.

Dunshea FR, King RH, Eason PJ, Campbell RG. Interrelationships between dietary ractopamine, energy intake, and sex in pigs. Aust. J. Agric. Res. 1998; 49(4): 565-574. 
Edmonds MS, Baker DH. Effect of dietary protein and lysine fluctuations in the absence and presence of ractopamine on performance and carcass quality of late-finishing pigs. J. Anim. Sci. 2010; 88(2): 604611.

Fain JN, García-Sáinz JA. Adrenergic regulation of adipocyte metabolism. J. Lipid Res.1983; 24: 945966.

Fernández-Dueñas DM, Myers AJ, Scramlin SM, Parks CW, Carr SN, Killefer J, et al. Carcass, meat quality, and sensory characteristics of heavy weight pigs fed ractopamine hydrochloride (Paylean). J. Anim. Sci.2008; 86(12): 3544-3550.

Grant AL, Helferich WG, Merkel RA, Bergen WG. Effects of phenethanolamines and propranolol on the proliferation of cultured chick breast muscle satellite cells. J. Anim. Sci.1990; 68(3): 652-658.

Grant AL, Skjaerlund DM, Helferich WG, Bergen WG, Merkel RA. Skeletal muscle growth and expression of skeletal muscle alpha-actin mRNA and insulin-like growth factor I mRNA in pigs during feeding and withdrawal of ractopamine. J. Anim. Sci. 1993; 71(12): 3319-3326.

Halsey CHC, Weber PS, Reiter SS, Stronach BN, Bartosh JL, Bergen WG. The effect of ractopamine hydrochloride on gene expression in adipose tissues of finishing pigs. J. Anim. Sci. 2011; 89(4): 10111019.

Hinson RB, Wiegand BR, Ritter MJ, Allee GL, Carr SN. Impact of dietary energy level and ractopamine (Paylean) on growth performance, carcass characteristics, and meat quality of finishing pigs. $J$. Anim. Sci. 2011; 89(11): 3572-3579.

Jacela JY, Dritz SS, Tokach MD, DeRouchey JM, Goodband RD, Nelssen JL. Effect of constant or stepup ractopamine $\mathrm{HCl}$ (Paylean) feeding programs on growth performance and carcass characteristics of late-finishing pigs. In: Kansas State University Swine Day: Proceedings: Finishing Pig Nutrition and Management; 2009. Available from: http://www.ksre.ksu.edu/library/lvstk2/srp1020.pdf.

Johnson M. Molecular mechanisms of $\beta 2$-adrenergic receptor function, response, and regulation. J. Allergy Clin. Immunol. 2006; 117(1): 18-24.

Kiefer C, Sanches JF. Metanálise dos níveis de ractopamina em dietas para suínos em terminação. Rev. Bras. Zootec. 2009; 38(6): 1037-1044. Portuguese.

Kuiper HA, Noordam MY, van Dooren-Flipsen MM, Schilt R, Roos AH. Illegal use of beta-adrenergic agonists: European Community. J. Anim. Sci. 1998; 76(1): 195-207.

Kutzler LW, Peterson CM, Ellis M, Carr SN, Ritter MJ, Armstrong TA, et al. Ractopamine (Paylean) response in heavy-weight finishing pigs. Prof. Anim. Sci. 2010; 26(2): 243-249.
Lands AM, Arnold A, Mcauliff JP, Luduena FP, Brown TG. Differentiation of receptor systems activated by sympathomimetic amines. Nature 1967; 214(5088): 597-598.

Leick CM, Puls CL, Ellis M, Killefer J, Carr TR, Scramlin SM, et al. Effect of distillers dried grains with solubles and ractopamine (Paylean) on quality and shelf-life of fresh pork and bacon. J. Anim. Sci. 2010; 88(8): 2751-2766.

Li N, Preckel KAF, Schinckel AP. Analysis of economically optimal nutrition and marketing strategies for Paylean usage in hog production. $J$. Agr. Resource Econ. 2003; 28(2): 272-286.

Liang W, Mills SE. Quantitative analysis of betaadrenergic receptor subtypes in pig tissues. J. Anim. Sci. 2002; 80(4): 963-970.

Liu CY, Mills SE. Decreased insulin binding to porcine adipocytes in vitro by beta-adrenergic agonists. $J$. Anim. Sci. 1990; 68(6): 1603-1608.

Liu CY, Grant AL, Kim KH, Ji SQ, Hancock DL, Anderson DB, et al. Limitations of ractopamine to affect adipose tissue metabolism in swine. J. Anim. Sci. 1994; 72(1): 62-67.

Lohse MJ, Benovic JL, Codina J, Caron MG, Lefkowitz RJ. Beta-arrestin: a protein that regulates betaadrenergic receptor function. Science 1990; 248(4962): 1547-1550.

Main RG, Dritz SS, Tokach MD, Goodband RD, Nelssen JL, DeRouchey JM. Effects of ractopamine $\mathrm{HCl}$ dose and treatment period on pig performance in a commercial finishing facility. J. Swine Health Prod. 2009; 17(3): 134-139.

Marchant-Forde JN, Lay Jr. DC, Pajor EA, Richert BT, Schinckel AP. The effects of ractopamine on the behavior and physiology of finishing pigs. J. Anim. Sci. 2003; 81(2): 416-422.

Marinho PC, Fontes DO, Silva FCO, Silva MA, Pereira FA, Arouca CLC. Efeito dos níveis de lisina digestível e da ractopamina sobre o desempenho e as características de carcaça de suínos machos castrados em terminação. Rev. Bras. Zootec. 2007; 36(6): 17911798. Portuguese.

McNeel RL, Mersmann HJ. Distribution and quantification of beta1-, beta2-, and beta3-adrenergic receptor subtype transcripts in porcine tissues. $J$. Anim. Sci. 1999; 77(3): 611-621.

Mersmann HJ. Overview of the effects of betaadrenergic receptor agonists on animal growth including mechanisms of action. J. Anim. Sci. 1998; 76(1): 160-172.

Mills SE, Liu CY, Gu Y, Schinckel AP. Effects of ractopamine on adipose tissue metabolism and insulin binding in finishing hogs: Interaction with genotype and slaughter weight. Domest. Anim. Endocrinol. 1990; 7(2): 251-264. 
Mills SE. Beta-adrenergic receptor subtypes mediating lipolysis in porcine adipocytes. Studies with BRL37344, a putative $\beta 3$-adrenergic agonist. Comp. Biochem. Physiol. C. 2000; 126(1): 11-20.

Mills SE. Biological basis of the ractopamine response. J. Anim. Sci. 2002a; 80(2): E28-E32.

Mills SE. Implications of feedback regulation of betaadrenergic signaling. J. Anim. Sci. 2002b; 80(1): E30E35.

Mills SE, Kissel J, Bidwell CA, Smith DJ. Stereoselectivity of porcine $\beta$-adrenergic receptors for ractopamine stereoisomers. J. Anim. Sci. 2003a; 81(1): 122-129.

Mills SE, Spurlock ME, Smith DJ. $\beta$-adrenergic receptor subtypes that mediate ractopamine stimulation of lipolysis. J. Anim. Sci. 2003b; 81(3): 662-668.

Moore KL, Dunshea FR, Mullan BP, Hennessy DP, D'Souza DN. Ractopamine supplementation increases lean deposition in entire and immunocastratedd male pigs. Anim. Prod. Sci. 2009; 49(12): 1113-1119.

Neill CR, Goodband RD, Tokach MD, Nelssen JL, Dritz SS, DeRouchey JM, et al. Effects of intermittent ractopamine hydrochloride use on pig growth performance in late finishing. Prof. Anim. Sci. 2010; 26(2): 239-242.

Page KA, Hartzell DL, Li C, Westby AL, Della-Fera MA, Azain MJ, et al. $\beta$-adrenergic receptor agonists increase apoptosis of adipose tissue in mice. Domest. Anim. Endocrinol. 2004; 26(1): 23-31.

Peterla TA, Scanes CG. Effect of $\beta$-adrenergic agonists on lipolysis and lipogenesis by porcine adipose tissue in vitro. J. Anim. Sci. 1990; 68(4): 1024-1029.

Poletto R, Rostagno MH, Richert BT, Marchant-Forde JN. Effects of a "step-up" ractopamine feeding program, sex, and social rank on growth performance, hoof lesions, and Enterobacteriaceae shedding in finishing pigs. J. Anim. Sci. 2009; 87(1): 304-313.

Poletto R, Cheng HW, Meisel RL, Garner JP, Richert BT, Marchant-Forde JN. Aggressiveness and brain amine concentration in dominant and subordinate finishing pigs fed the $\beta$-adrenoreceptor agonist ractopamine. J. Anim. Sci. 2010; 88(9): 3107-3120.

Qiang Z, Shentu F, Wang B, Wang J, Chang J, Shen J. Residue depletion of ractopamine and Its metabolites in swine tissues, urine, and serum. J. Agr. Food Chem. 2007; 55(11): 4319-4326.

Reiter SS, Halsey CHC, Stronach BJ, Bartosh JL, Owsley WF, Bergen WG. Lipid metabolism related gene-expression profiling in liver, skeletal muscle and adipose tissue in crossbred Duroc and Pietrain pigs. Comp. Biochem. Physiol. Part D 2007; 2(3): 200-206.
Ricke EA, Smith DJ, Feil VJ, Larsen GL, Caton JS. Effects of ractopamine $\mathrm{HCl}$ stereoisomers on growth, nitrogen retention, and stereoisomers on growth, nitrogen retention, and carcass composition in rats. $J$. Anim. Sci. 1999; 77(3): 701-707.

Rikard-Bell C, Curtis MA, van Barneveld RJ, Mullan BP, Edwards AC, Gannon NJ, et al. Ractopamine hydrochloride improves growth performance and carcass composition in immunocastratedd boars, intact boars, and gilts. J. Anim. Sci. 2009; 87(11): 3536-3543.

Sainz RD, Kim YS, Dunshea FR, Campbell RG. Effects of ractopamine in pig muscles: Histology, calpains and $\beta$-adrenergic receptors. Aust. J. Agr. Res. 1993; 44(7): 1441-1448.

Sakai T, Hitomi T, Sugaya K, Kai S, Murayama M, Maitani T. Determination Method for Ractopamine in Swine and Cattle Tissues Using LC/MS. J. Food Hyg. Soc. Japan 2007; 48(5): 144-147.

Shen J, Zhang Z, Yao Y, Shi W, Liu Y, Zhang S. Timeresolved fluoroimmunoassay for ractopamine in swine tissue. Anal. Bioanal. Chem. 2007; 387(4): 1561-1564.

Schaefer AL, Jones SDM, Tong AKW, dePassille AMB, Rushen J, Merrill JK. The effect of feeding the beta-adrenergic agonist ractopamine on the behavior of market-weight pigs. Can. J. Anim. Sci. 1992; 72(1): 15-21.

Schinckel AP, Richert BT, Kendall DC [Internet]. 2001 [update 2011 Jan 16, cited 2011 Jan 16]. Modeling the response to Paylean and dietary lysine requirements. Available from: http://www.ansc.purdue.edu/swine/swineday/sday01/ 4.pdf.

Schinckel AP, Richert BT, Herr CT. Variation in the response of multiple genetic populations of pigs to ractopamine. J. Anim. Sci. 2002; 80(2): E85-E89.

Schinckel AP, Li N, Richert BT, Preckel PV, Einstein ME. Development of a model to describe the compositional growth and dietary lysine requirements of pigs fed ractopamine. J. Anim. Sic. 2003, 81(15): 1106-1119.

Schinckel AP, PAS, Li N, Richert BT, Preckel P, Foster $\mathrm{K}$, Einstein ME. Development of a model to describe the compositional growth and dietary lysine requirements of pigs fed increasing dietary concentrations of ractopamine. Prof. Anim. Sci. 2006; 22(6): 438-449.

See MT, Armstrong TA, Weldon WC. Effect of a ractopamine feeding program on growth performance and carcass composition in finishing pigs. J. Anim. Sci. 2004; 82(8): 2474-2480.

Smith CK. Affinity of phenethanolamines for skeletel muscle beta-adrenergic receptors and influence on receptor down-regulation. J. Anim. Sci. 1989; 67(1): 190. 
Smith DJ. The pharmacokinetics, metabolism, and tissue residues of $\beta$-adrenergic agonists in livestock. J. Anim. Sci. 1998; 76(1): 173-194.

Smith DJ, Shelver WL. Tissue residues of ractopamine and urinary excretion of ractopamine and metabolites in animals treated for 7 days with dietary ractopamine. J. Anim. Sci. 2002; 80(5): 1240-1249.

Spurlock ME, Cusumano JC, Ji SQ, Anderson DB, Smith II CK, Hancock DL, Mills SE. The effect of ractopamine on $\beta$-adrenoceptor density and affinity in porcine adipose and skeletal muscle tissue. J. Anim. Sci. 1994; 72(1): 75-80.

Ungerer M, Kessebohm K, Kronsbein K, Lohse MJ, Richardt G. Activation of beta-adrenergic receptor kinase during myocardial ischemia. Circ. Res. 1996; 79(3): 455-460.

USDA - Livestock and poultry: world markets and trade [Internet]. 2011 Out 10 [update 2011 Out 2, cited 2011 Out 2].Available from: http://www.fas.usda.gov/dlp/circular/2011/livestock_ poultry.pdf.

Weber TE, Richert BT, Belury MA, Gu Y, Enright K, Schinckel AP. Evaluation of the effects of dietary fat, conjugated linoleic acid, and ractopamine on growth performance, pork quality, and fatty acid profiles in genetically lean gilts. J. Anim. Sci. 2006; 84(3): 720732.
Webster MJ, Goodband RD, Tokach MD, Nelssen JL, Dritz SS, Unruh JA, et al. Interactive effects between Paylean (ractopamine $\mathrm{HCl}$ ) and dietary lysine on finishing pig growth performance, carcass characteristics and tissue accretion. Prof. Anim. Sci. 2007; 23(2): 597-611.

Williams NH, Cline TR, Schinckel AP, Jones DJ. The impact of ractopamine, energy intake, and dietary fat on finisher pig growth performance and carcass merit. J. Anim. Sci. 1994, 72(12): 3152-3162.

Xiong YL, Gower MJ, Li C, Elmore CA, Cromwell GL, Lindemann MD. Effect of dietary ractopamine on tenderness and postmortem protein degradation of pork muscle. Meat Sci. 2006; 73(4): 600-604.

Zhai F, Huang Y, Li C, Wang X, Lai K. Rapid determination of ractopamine in swine urine using surface-enhanced Raman spectroscopy. J. Agric Food Chem. 2011; 59(18): 10023-10027.

Zhang Y, Wang F, Fang L, Wang S, Fang G. Rapid determination of ractopamine residues in edible animal products by enzyme-linked immunosorbent assay: development and investigation of matrix effects. J. Biomed. Biotechnol. 2009; 2009: 1-9.

Received: May 11, 2011; Revised: September 27, 2011; Accepted: February 13, 2012. 